\title{
COMPLEMENTARITY OF THE MEASURES OF THE COMMON AGRICULTURAL POLICY AND THE COHESION POLICY FOR RURAL DEVELOPMENT BETWEEN 2021 AND 2027 IN THE LIGHT OF PROGRAMING DOCUMENTS
}

\author{
ADAM WASILEWSKI \\ JULIAN KRZYŻANOWSKI \\ PAWEŁ CHMIELIŃSKI
}

\begin{abstract}
The aim of the study was to determine the complementarity of the Cohesion Policy and the Common Agricultural Policy in terms of their impact on the development of rural areas between 2021 and 2027. In their research, the authors paid particular attention to the distribution of support between the aforementioned policies in the context of social and economic problems occurring in rural areas. The empirical material consisted of literature on the subject and documentation related to the preparation and implementation of the analyzed policies.

The analysis of documents, literature on the subject and practice indicates a growing need to demonstrate the complementarity of both policies in the process of programing individual development instruments, especially in the territorial dimension, where the separation of individual aspects of socio-economic life is extremely difficult, hence the need for a cross-sector approach, definition, and response to local challenges.
\end{abstract}

Keywords: cohesion policy, common agricultural policy, complementarity of public policies.

JEL codes: J24, O18, O21, Q58.

Adam Wasilewski, DEng, Institute of Agricultural and Food Economics - National Research Institute, Department of Agricultural Economy, Agricultural Policy and Rural Development; ul. Świętokrzyska 20, 00-002 Warsaw, Poland (adam.wasilewski@ierigz.waw.pl). ORCID iD: 0000-0003-0863-3219. Julian Krzyżanowski,PhD, DSc, Assoc. Prof. of IAFE-NRI, Institute of Agricultural and Food Economics National Research Institute, Department of Agricultural Economy, Agricultural Policy and Rural Development; ul. Świętokrzyska 20, 00-002 Warsaw, Poland(julian.krzyzanowski@ierigz.waw.pl). ORCID iD: 0000-0001-6418-154X.

Paweł Chmieliński, PhD, DSc, institute of Rural and Agricultural Development - Polish Academy of Sciences, Department of European Integration; ul. Nowy Świat 72, 00-330 Warszawa (pchmielinski@ irwirpan.waw.pl). ORCID iD: 0000-0001-8377-0702. 


\section{Introduction}

The decisions regarding the distribution of funds, and the complementarity of the impact of the Cohesion Policy (CP) and the Common Agricultural Policy (CAP) for the support of rural development and the agri-food sector in the 2014-2020 perspective, had a significant impact on the effect of scale of public support and the territorial development of Polish villages (Czyżewski and Stępień, 2015). From the point of view of achieving the objectives of economic policy, it is necessary to identify solutions constituting the basis of a partnership agreement in the next programming period as the basic tool for coordinating and planning a rural development policy (Bachtler and Mendez, 2020).

This study aims to discuss selected areas of complementarity of measures implemented under the CAP and the CP, with particular emphasis on issues directly affecting the quality of life and socio-economic development in rural areas. The complementarity of individual instruments of the above-mentioned policies is considered in terms of infrastructure investment, investment at the level of households in rural areas, as well as conceptual and strategic solutions (mainly concerning the organization of support at the national and regional level) (WISA Europa, 2017). A separate issue is to determine the streams of support for individual areas of rural development under the individual funds (Wallace, Pollack, Roederer-Rynning and Young, (eds.), 2020); therefore, the considerations made in this study also raise the issue of the lack of adequate addressing of support for rural problems under the conditions of dispersed sources of financing and a sectoral approach to the urban-rural relations (Rauhut and Humer, 2020).

The analysis covers EU legislative projects, reports on the evaluation of the 2014-2020 Rural Development Program (RDP), and operational programs, the results of the STRATEG monitoring, the content of national and regional operational programs, the 2014-2020 RDP, the 2014-2020 Partnership Agreements, and unpublished materials from ministerial working groups on the objectives of the Cohesion Policy. Due to the specific conditions of creating new foundations for development as a result of the impact of the COVID-19 pandemic on the socioeconomic situation of the country and, the economic policy response to the crisis caused by this, the analysis also covered the National Recovery Plan (NRP) as an additional important pillar of rural development in the issues discussed (Watzka and Watt, 2020).

\section{Development policy and the National Recovery Plan}

After 2020, stronger coordination of the CP with the EU actions (Ministry of Development Funds..., 2020) in other areas, notably economic governance and structural reforms, is widely expected (Rauhut and Humer, 2020). This will be 
the case in particular for the European Semester ${ }^{1}$ and the European Pillar of Social Rights. ${ }^{2}$ Given the change in the basket of funds covered by the provisions of the general regulation and the exclusion of the European Agricultural Fund for Rural Development (EAFRD) from it, there is a need for stronger coordination and complementarity also with the Common Agricultural Policy (CAP).

In the 2021-2027 perspective, all CAP measures will be programmed under the CAP 2021-2027 Strategic Plan (CAPSP) which is the flagship document for the implementation of the CAP in Poland for 2021-2027. The European Agricultural Fund for Rural Development will not be an element of the Partnership Agreement, unlike in 2014-2020. Therefore, it will be all the more important to program complementary rural measures under the PA and the CAPSP, especially with regard to modern rural development instruments, such as the concept of "smartness" (Artelaris and Mavrommatis, 2020).

The new development policy tool available from 2020 is the Recovery and Resilience Facility (RRF) (Ministry of Economic Development..., 2020), the largest of the proposed support instruments under theEuropean Recovery Instrument (ERI), amounting to EUR 672.5 billion (in 2018 fixed prices), of which EUR 312.5 billion is to be allocated to non-repayable support (grants) and EUR 360 billion to loans. The ERI complements the Multiannual Financial Framework for 2021-2027. Poland is the fourth largest beneficiary of this program, and the support it offers will be implemented through the National Recovery Plan. However, the establishment of this instrument, aimed at dealing with the negative effects of the pandemic, has resulted in some delays in policy implementation which may begin at the end of 2021 at the earliest.

The overall objective of the RRF is to promote the economic, social, and territorial cohesion of the Union by increasing the resilience and adaptability of the Member States, mitigating the social and economic effects of the crisis, and supporting the ecological and digital transformation. Thus, the RRF is expected to contribute to restoring growth potential, implementing reforms, and public investment projects in the form of a coherent package.

\footnotetext{
${ }^{1}$ During the European Semester, Member States align their fiscal and economic policies with the objectives and principles agreed at the EU level. The most important part of the procedure falls in the first six months of the year (semester), during which three branches of economic policy are coordinated, namely: structural reforms to promote growth and jobs in line with the Europe 2020 strategy, fiscal policy to ensure the sustainability of public finances in line with the Stability and Growth Pact, and the prevention and correction of excessive macroeconomic imbalances.

${ }^{2}$ The European Pillar of Social Rights Action Plan sets out specific actions to further implement the principles of the European Pillar of Social Rights as a joint effort of Member States and the EU, with the active participation of the social partners and civil society. It also proposes the EU headline targets on employment, skills, and social protection to be achieved by 2030 .
} 
According to the available data, the RRF provides for Poland: ${ }^{3}$

- approx. EUR 23.1 billion in the form of non-returnable funds for grants,

- approx. EUR 34.2 billion in the form of possible loans.

The condition for obtaining support under the facility is the presentation of the National Recovery Plan to the EC, subject to its consistency with the documents prepared under the so-called the European Semester procedure. In addition, it should identify reforms and investments that strengthen the country's growth potential, and economic and social resilience, and enhance territorial cohesion. According to a specific framework, it should also propose actions which have a positive impact on green and digital socio-economic changes (Copeland and Daly, 2018).

Support is provided under four components of resilience: society, economy, environment, and state. Projects in the field of social resilience are aimed at supporting knowledge and skills, and they are addressed to both persons at various stages of education and workers. The transition to a digital economy is one of the most important long-term goals of the NRP. Investment in new technologies is aimed at improving the situation in terms of connections, cooperation, and functioning of society, offices, and entrepreneurs, so that the digital economy may be more competitive, modern, and open to the challenges of the future (Artelaris and Mavrommatis, 2020). Projects in the field of environmental resilience also aim to support the process of green transformation of the Polish economy within the scope of actions consistent with the objectives of the European Green Deal (see Wrzaszcz and Prandecki, 2020).

Due to restrictions in movement within Europe resulting from the COVID-19 pandemic, on 20 July 2020 the 2020/2021 recommendations for individual Member States on National Reform Programs and Stability or Convergence Programs were adopted by the Agriculture and Fisheries Council (European Commision, 2020), which recommends that Poland take measures in 2020-2021 to:

1. Implement fiscal policies aimed at achieving prudent medium-term fiscal positions and ensuring long-term debt sustainability, while enhancing investment.

2. Improve resilience, accessibility, and effectiveness of the health system, among others by providing sufficient resources and accelerating the deployment of e-health services.

3. Mitigate the impact of the crisis on employment, in particular by enhancing flexible forms of work organization and reduced work schedule.

4. Continue efforts to secure access to finance and liquidity for companies.

5. Enhance the investment climate, in particular by safeguarding judicial independence.

\footnotetext{
${ }^{3}$ National Recovery and Resilience Plan (KPO), (2020). Website of the Republic of Poland GOV.PL. https:// www.gov.pl/web/planodbudowy (access date: 11.10. 2020).
} 


\section{Complementarity of measures of rural and cohesion policy and the National Recovery Plan}

The coexistence of the Cohesion Policy, the Common Agricultural Policy and the Recovery Program brings opportunities and challenges resulting from the potential synergy effects of the impact of these programs on rural development (Mikuš, Kukoč, and Rogelj, 2019; Chmieliński and Gospodarowicz, 2018), and at the same time creates the problem of proper distribution of support so as to avoid duplication of competences and double financing of investments of a uniform type (Żbik, 2017). The NRP is assumed to have an impact on areas important for the development of rural areas, but not covered by the Cohesion Policy or covered by this policy in these areas where the NRP may be a supplementary source of financing (Table 1).

When analyzing the process of dividing the support within individual funding streams, a general rule can be noted that wherever it is not about direct agricultural production, support from the Cohesion Policy can be used (Calegari, Fabrizi, Guastella, and Timpano, 2020). In addition, this policy usually finances larger investments, not covered by rural funds (Calabrò and Cassalia, 2017). As far as the scope of support is concerned, the NRP funds should have a supplementary and important function in relation to both programs. The complementarity of the impact of all three funding streams for investment and social projects is presented in Table 1. Itcan be indicated that the NRP, in its broad thematic scope, is closer to the support profile implemented under the Cohesion Policy. Circular economy and revitalization of villages and small towns are the fields with a clear coexistence of the stream of support under the policies, and at the same time key areas for the future regional development of the economy and for rural areas,. In other cases, the division and complementarity of the planned instruments under both policies and the NRP are quite clear. One example is investment in transport and energy in rural areas, which are assumed to be mainly the domain of support from the Cohesion Policy. Both planning documents ${ }^{4}$ and literature on the subject indicate that it is justified to involve more cohesion policy funds than before for the development of entrepreneurship, acquisition of skills and competence necessary on the non-agricultural labor market (including digital competence), increasing territorial accessibility, investment attractiveness of rural areas (remote commuting to and from work, investment areas with infrastructure and accessibility) and social development and inclusion, poverty reduction, and occupational mobility of people leaving agriculture (Bachtler, Berkowitz, Hardy, and Muravska, 2017).

\footnotetext{
${ }^{4}$ Initial position of the Ministry of Agriculture regarding support under CP 2 - in the scope of: selective municipal waste collection points, minimization of waste generation in production processes, food waste infrastructure, educational activities in the framework of the circular economy, in particular in the waste management sector, the scope of support for the development of green infrastructure in the urban environment (from September 2019), pp. 49-50.
} 
Table 1

Areas of complementarity of the CAP, CP, and NRP

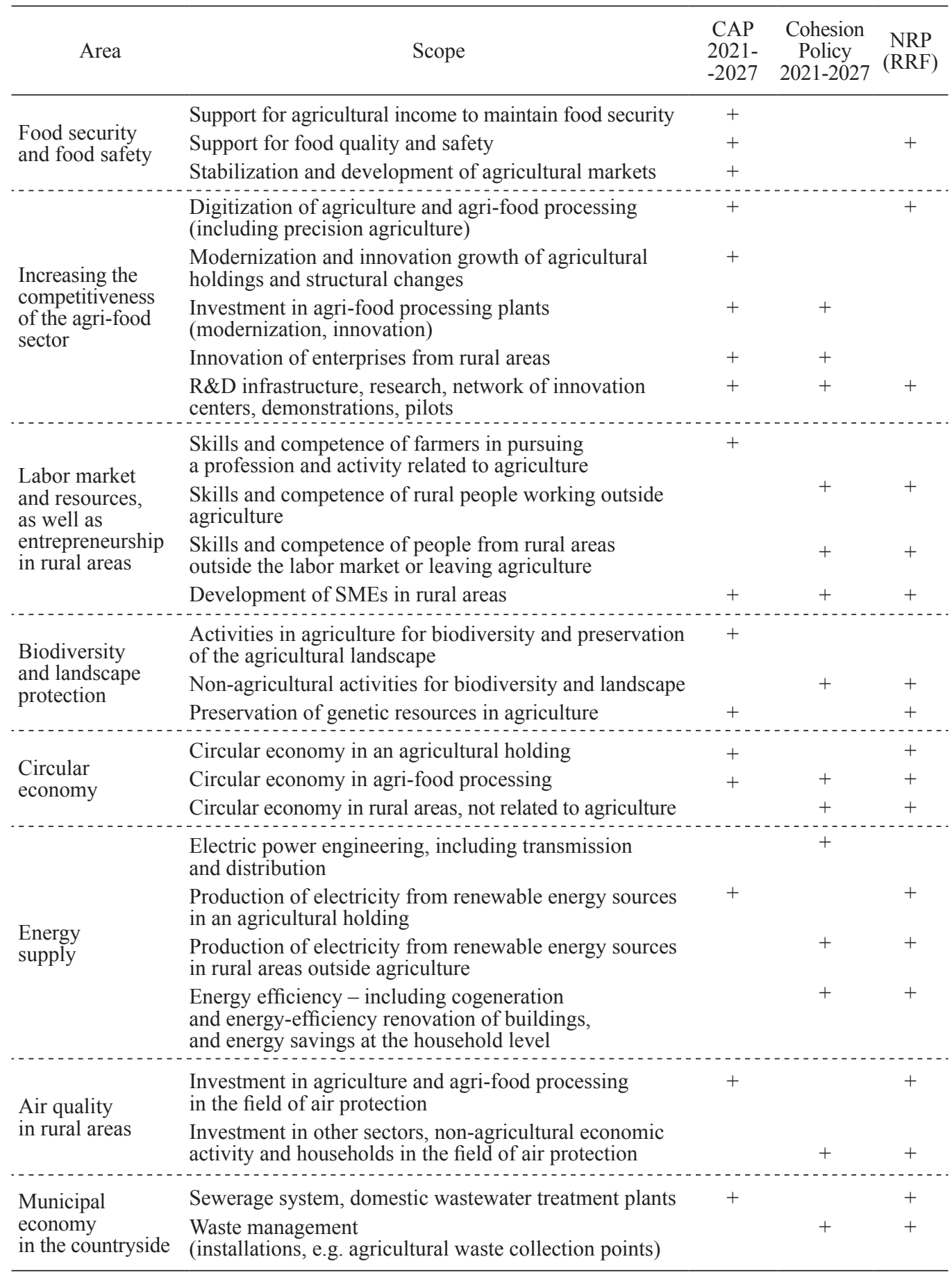


cont. Table 1

\begin{tabular}{|c|c|c|c|c|}
\hline Area & Scope & $\begin{array}{l}\text { CAP } \\
2021- \\
-2027\end{array}$ & $\begin{array}{l}\text { Cohesion } \\
\text { Policy } \\
\text { 2021-2027 }\end{array}$ & $\begin{array}{l}\mathrm{NRP} \\
(\mathrm{RRF})\end{array}$ \\
\hline \multirow{4}{*}{$\begin{array}{l}\text { Water resources } \\
\text { and their quality }\end{array}$} & $\begin{array}{l}\text { Investment in water retention and storage } \\
\text { for agricultural activities }\end{array}$ & + & + & + \\
\hline & $\begin{array}{l}\text { Investment in water retention and storage for public } \\
\text { purposes }\end{array}$ & & \multirow{3}{*}{+} & \\
\hline & $\begin{array}{l}\text { Investment in the field of flood safety, including } \\
\text { investment in drainage }\end{array}$ & & & + \\
\hline & $\begin{array}{l}\text { Access to drinking water in rural areas } \\
\text { (water supply investment) }\end{array}$ & & & + \\
\hline \multirow{5}{*}{$\begin{array}{l}\text { Infrastructure } \\
\text { and public } \\
\text { services, } \\
\text { tourism }\end{array}$} & $\begin{array}{l}\text { Health, including the impact of nutrition on health, } \\
\text { public health infrastructure }\end{array}$ & + & + & + \\
\hline & $\begin{array}{l}\text { Childcare services for children from the age of } 3 \text {, } \\
\text { education at the primary and school level }\end{array}$ & & + & \\
\hline & $\begin{array}{l}\text { Sport and tourism } \\
\text { (infrastructure and services in rural areas) }\end{array}$ & & + & \\
\hline & Care services and infrastructure & & + & + \\
\hline & Social housing & & + & + \\
\hline \multirow{4}{*}{$\begin{array}{l}\text { Territorial } \\
\text { accessibility } \\
\text { of rural areas }\end{array}$} & TEN-T road infrastructure & & + & + \\
\hline & National road infrastructure and voivodship roads & & + & + \\
\hline & $\begin{array}{l}\text { Local infrastructure (district and municipal roads), } \\
\text { bicycle paths }\end{array}$ & + & + & + \\
\hline & $\begin{array}{l}\text { Public transport (including low-carbon transport) } \\
\text { and infrastructure of transfer nodes }\end{array}$ & & + & + \\
\hline \multirow{4}{*}{$\begin{array}{l}\text { Digitization } \\
\text { of rural areas } \\
\text { and services }\end{array}$} & $\begin{array}{l}\text { Large digital infrastructure } \\
\text { (including broadband and } 5 \mathrm{G} \text { internet) }\end{array}$ & & + & + \\
\hline & E-services in agriculture & + & & + \\
\hline & Digitization of public services, e-administration & & + & + \\
\hline & Accessibility of networks in public space (Hot-spots) & & + & \\
\hline \multirow{3}{*}{$\begin{array}{l}\text { Investment } \\
\text { regeneration } \\
\text { of villages } \\
\text { and small towns }\end{array}$} & $\begin{array}{l}\text { Aesthetics of public space, including public greenery, } \\
\text { regeneration }\end{array}$ & + & + & + \\
\hline & $\begin{array}{l}\text { Protection of the cultural heritage of rural areas and } \\
\text { agriculture }\end{array}$ & + & + & + \\
\hline & Shaping the spatial order and zone & & + & + \\
\hline \multirow{3}{*}{$\begin{array}{l}\text { Community-led } \\
\text { development } \\
\text { and collaboration }\end{array}$} & $\begin{array}{l}\text { Support for bottom-up initiatives and building } \\
\text { cooperation competence }\end{array}$ & + & + & \\
\hline & Establishing cross-sector partnerships & + & + & \\
\hline & $\begin{array}{l}\text { Development of cooperation and collaboration } \\
\text { in the agri-food sector }\end{array}$ & + & & \\
\hline
\end{tabular}

Source: Assumptions for programming rural development from European funds for 2021-2027, materials of the MARD for the meeting with the EC on the demarcation of the CP and the CAP, Warsaw. 4 November 2020. 
A detailed analysis of the delimitation provisions included in Table 1 proves the thesis that in the cases which do not concern direct agricultural production and agricultural holding, as well as larger investment in rural areas, support from the Cohesion Policy and the RRF funds may be used. This is confirmed by the trend observed in recent decades in the development of individual policies in the European Union countries which promotes the Cohesion Policy as one that solves socio-economic problems in rural areas (in the context of regional development and functional connections in cities), while narrowing down the impact of agricultural policy (CAP) to production and environmental issues in the agricultural sector (Dax and Copus, 2018; Wieliczko, 2017).

\section{Technical infrastructure}

The analysis of planning documents being the basis for delimiting the support streams, presented in Table 1, indicated that one of the most important aspects of implementation of the development policy towards rural areas is the issue related to technical infrastructure. First of all, this includes insufficient coverage of the water and sewerage network in rural areas which remains one of the fundamental problems identified in research on the needs of local governments (Jaworska-Księżak, 2019; Sierak, 2017).

Research carried out at the end of 2016 (IERiGŻ-PIB, 2016) indicates that full satisfaction of the rural population's water supply needs would require an investment of PLN 9.6 billion. Connecting 95\% of the inhabitants of each rural and urban-rural municipality to the collective water supply network would reduce the costs of water supply investment to approximately PLN 7.1 billion. It should be noted that urbanrural and rural municipality declare their own contribution to water supply investment at an average level of about $29 \%$. The need for investment in the expansion of the sewerage network in rural areas is even greater than in the case of water supply investments. Research carried out by the Institute of Agricultural and Food Economics - National Research Institute (IERiGŻ-PIB, 2018) shows that in order to fully meet the needs for the expansion of the sewerage network in rural areas, approximately PLN 19 billion should be invested. Funds for the "necessary" sewerage investment should be guaranteed as part of the Cohesion Policy. They concern the provision of access to a collective sewerage network in villages with a population of over 2,000. The scale of these investments would be much smaller. The estimated cost of sewerage investment amounts to around PLN 3.5 billion, and the expected support by municipal governments is approximately PLN 2.7 billion.

The division of competence and the resulting assumptions for the allocation of funds in the 2021-2027 financial perspective clearly indicate the inability to solve the problem of the lack of foundations for investment in water and sewerage infrastructure under the CAP funding. It can be assumed that it is under the CP that one should turn for the possibility of creating programs and allocating funds for measures related to the construction and modernization of this network in rural areas, as well as domestic wastewater treatment plants in households located peripher- 
ally to settlement clusters and in areas which are difficult to access. The abovementioned research allowed for determining the distribution of funds allocated to possible water supply and sewerage investment in rural areas among individual voivodships. The regional demand for water supply investment varies significantly, which should be taken into account when planning the regional distribution of funds within the Cohesion Policy (Komornicki et al., 2018; Berkowitz, Monfort, and Pieńkowski, 2019).

The analysis of program documents indicates that financing investment activities, such as energy-efficiency renovation projects aimed at improving the energy efficiency, investment in renewable energy sources, sustainable use of water and other resources, will come from the Cohesion Policy funds. Financing renewable energy sources solely from the Cohesion Policy may, however, raise some concerns about the availability of funds and sources of financing for the construction of installations providing energy not only for households, but also for agricultural holdings, especially with regard to the economic justification of such a division (Dybikowska and Graczyk, 2019; Rogowska, 2017; Graczyk, 2017). Energy consumption in livestock production or special sections of agricultural production is relatively high, which is why the question arises whether farmers will be able to use support under the cohesion policy for the construction of installations with a capacity that will also enable the use of generated energy for production purposes (Wysokiński, Trębska, and Gromada, 2017). The issues related to the energy-efficiency renovation of buildings in which livestock production is carried out appear to be similar.

\section{Digital transformation of the country}

The literature indicates that digital transformation, also in relation to rural areas, has been the domain of the Cohesion Policy and related regional development instruments for years. Digitization also contributes to reducing differences in the income of rural and urban population (Czapiewski et al., 2013). Its development in rural areas will make it possible to undertake and conduct economic activity in these areas which so far has been specific only to urban areas, due to their access to broadband internet (Haefner and Sternberg, 2020). Examples include accounting, design and IT services or the development of e-commerce (Mączyńska and Okoń-Horodyńska, 2020). An additional factor supporting the development of certain services may be the fact that rural areas have a large warehouse space at much lower prices, including rental prices. The consequence of digitization of rural areas may be a deceleration or even reversal of the depopulation process in peripheral areas, and slowing down of the aging process of the rural population. This will be facilitated by infrastructure projects implemented under the NRP aimed at expanding access to broadband networks (Ministry of Development Funds..., 2020a). 


\section{Labor market}

Labor market support for the rural population within the framework of the cohesion policy instruments is to allow for the integration of measures in terms of labor supply and demand (as entrepreneurship grows). Attention should be paid to broadening gap in the education level of the rural and urban population (Rosner and Stanny, 2019). Although the share of people with higher education in rural areas is systematically increasing, the pace of this growth is slower than in cities. Moreover, the increased share of the population with higher education in rural areas is to some extent due to the influx of urban population to areas adjacent to large urban agglomerations. Additionally, a permanent feature of rural areas is that the local market for people with higher education is relatively small (Kłodziński, 2010). On the other hand, the experience gained during the pandemic shows that the development of the rural labor market for people with higher education is possible thanks to the partial or complete digitization of some professions (Radlińska, 2020). The Cohesion Policy can develop instruments supporting the development of those sectors of the economy in rural areas which will require higher and often specialist education. In the long term, this will counteract the excessive concentration of the population in urban areas (Hölzel and de Vries, 2021).

An important question, from the point of view of the functioning of the labor market, are demographic and social issues contributing to the proper development of rural areas, in particular the problem of defeminization of rural areas. Since 2004, the rate of feminization of rural areas has been systematically deteriorating, and now equals approximately 101 (Statistics Poland, 2021; Szukalski, 2020). If this trend continues, it may significantly worsen the situation on the rural labor market. This may have negative effects in many sectors of the rural economy, e.g. there might be difficulties in maintaining commercial and basic services in villages, but also in the area of primary education or local government administration, due to the relatively significant share of women in the total number of employees in these sectors. Support measures in this regard may contribute to limiting the depopulation of peripheral rural areas. This is because this process does not apply to areas located in the vicinity of large urban agglomerations. Moreover, the de-feminization process is characterized by quite significant regional variability, which should be taken into account in the assumptions of support under the Cohesion Policy (Kiryluk-Dryjska, Beba, and Poczta, 2020).

\section{Agricultural and rural entrepreneurship}

Bearing in mind major changes in rural areas related to the issues of gradual disagrarization of rural areas, the basic elements of the discussion on the interaction of rural and cohesion policies include the scope of support for the development of nonagricultural functions of rural areas and agriculture, especially those related to the development of entrepreneurship (Chmieliński, Feltynowski, Jachymek, Przybyłowski, and Ziomek, 2008). What is particularly important in the process of creating the framework for programming instruments of individual policies is the proposal to 
reconsider the possibility of recognizing that an active farmer is an entrepreneur in the rules of support co-financed from the Cohesion Policy. ${ }^{5}$ Another argument in favor of broadening the definition of an entrepreneur is the fact that, according to Polish law, a business activity can be conducted without registration. However, the monthly income earned from this activity may not exceed $50 \%$ of the minimum remuneration in the country. These provisions also apply to farmers. Therefore, if an agricultural holding is a source of income for three persons, in 2021 it may receive additional income of up to PLN 4.2 thousand per month without the obligation to register the business activity (Kanarek-Równicka, 2020). Thus, agricultural holdings could develop, for example, small-scale processing without registering this activity. Farmers would be required to register their business only in the case of an increased production scale and improvement of development.

\section{Cohesion Policy and socio-territorial development}

The Cohesion Policy fulfills its social objectives, among others, by implementing specific objectives and types of intervention resulting from territorial strategies, including revitalization of degraded areas, carried out in a comprehensive manner, through integrated activities for the local community, as well as space and economy, implemented on the basis of appropriate revitalization programs (Minister for Economic Development, 2016). The Cohesion Policy assumes support for activities for the protection, development, and promotion of cultural heritage and services in the field of culture as important factors in the socio-economic development of a given area, as well as the security of public spaces, including the adaptation of public space, architecture, transport, and products for all citizens - seniors, people with disabilities, as well as, for example, pregnant women and parents with young children (Ministry of Development Funds..., 2021). All the above-mentioned areas in rural policy were developed under the so-called social component aimed at stiulating multifunctional development and the LEADER program, with theoption of choosing the concept of Community-Led Local Development (CLLD). ${ }^{6}$

\footnotetext{
5 "Propozycja kompleksowego podejścia do wspierania innowacyjności sektora rolno-spożywczego i MŚP na obszarach wiejskich w ramach Wspólnej Polityki Rolnej i polityki spójności w latach 2021-2027" ["Proposal for a Comprehensive Approach to Supporting Innovation in the Agri-Food Sector and SMEs in Rural Areas under the Common Agricultural Policy and the Cohesion Policy in 2021-2027"] in the initial position of the MARD on CP3 and partially CP1 regarding support for digitization (initial position of the MARD of November 2019), Warsaw.

6 "The CLLD is an instrument which, under the current financial perspective, allows for the application of the LEADER method also within the Cohesion Policy, under the common legal basis, i.e. Articles 32-35 of Regulation (EU) No 1303/2013 of the European Parliament and of the Council of 17 December 2013 laying down common provisions on the European Regional Development Fund, the European Social Fund, the Cohesion Fund, the European Agricultural Fund for Rural Development and the European Maritime and Fisheries Fund and laying down general provisions on the European Regional Development Fund, the European Social Fund, the Cohesion Fund and the European Maritime and Fisheries Fund and repealing Council Regulation (EC) No 1083/2006 (OJ EU L 347 of 20.12.2013, p. 320).”

Ministry of Agriculture and Rural Development (2020). Community-Led Local Development (CLLD), https:// www.gov.pl/web/rolnictwo/rozwoj-lokalny-kierowany-przez-spolecznosc-rlks (access date: 11.11.2020).
} 
As rural and regional measures are highly complementary in this respect, the effectiveness of the CLLD approach as an economic policy instrument at the local level, characterized by a cross-sectoral approach, is indicated more and more often (Miller, 2014; Pollermann, Raue and Schnaut, 2014). Moreover, the functional link between towns and villages still has a small, albeit increasing, reflection in individual policies whose sectoral approach has long been questioned in research (Tacoli, 1998).

The LEADER approach shows a modern direction in supporting the ability to cooperate in the social and territorial dimension. This approach proves that strengthening local communities as a multi-sector cooperation has measurable results, indicating the need to strengthen this direction of intervention under the RDP 2021-2027. It should be noted here that both policies in this area refer to the modern concept of Community-Led Local Development (CLLD) which, based on the LEADER approach, indicates the potential for adapting the CAP initiatives in the broadly understood development policy of the EU and the country (Komorowski, Mróz, and Stanny, 2021). In line with the implementation of the territorial approach in the Cohesion Policy, and in particular within the scope of activities under the priority objective 5 ('A Europe closer to citizens'), appropriate activities at the local and supra-local level were planned. This approach is in line with the conditions for undertaking interventions proposed by the European Commission that link interventions under the Cohesion Policy directly with territorial strategies ${ }^{7}$ (Integrated Territorial Investment - ITI, and other territorial instrument $-\mathrm{OTI}^{8}$ ) and local development strategies (for the CLLD) analyzing comprehensively the needs and the potential of a given territory. The activity in the framework of other initiatives will also play a significant role here, including the activities of local governments or social organizations as part of implementation projects (e.g. from the Horizon 2020 and Horizon Europe programs) and the like.

\section{Conclusions}

Based on selected examples, this study discusses and illustrates the areas of complementarity of measures implemented under the CAP and the CP, with particular emphasis on issues directly affecting the quality of life and socio-economic development in rural areas. The analysis of EU legislative projects, reports on the evaluation of the Rural Development Program and operational programs, as well as other scientific and practical materials, including conclusions form sessions of ministerial working groups on the CAP objectives and Cohesion Policy indicate, on the one hand, a growing need to demonstrate the complementarity of

\footnotetext{
${ }^{7}$ It is worth emphasizing that the basis for the implementation of objective 5 of the CP, i.e. "Enabling regions and people to address the social, economic and environmental impacts of the transition towards a climateneutral economy," will be territorial strategies, which means that when using territorial instruments it will be necessary to have a territorial strategy (ITI, OTI) and a local development strategy (CLLD).

${ }^{8} \mathrm{An}$ instrument aimed at solving problems, in particular of supra-local importance, requiring cooperation between local government units.
} 
both policies in the process of programming individual development instruments, especially in the territorial dimension, where it is extremely difficult to separate individual aspects of socio-economic life, hence the need for cross-sectoral approach, definitions, and responses to local challenges.

The need to support functional links with rural areas, which are an important place of life for people working in cities, becomes more and more evident in the policy towards cities, including even large agglomerations. It should be expected that along with the increasing popularization of remote working, rural areas will become more attractive in terms of settlement; therefore, their proper development in terms of digital, technical, as well as socio-cultural infrastructure will be a determinant of their future development, also in an economic sense. Agriculture is also facing the challenge of transformation towards local and supra-regional food systems, adapted to the needs in terms of the profile and quality of production (e.g. due to the need to change the diet to improve society's health, climate challenges, and environmental constraints), as well as the use of biomass in the developing bioeconomy.

It should also be pointed out that cooperation across borders is to be one of the main elements for rural development in the Cohesion Policy as a response to the need to build resilient local economies. It assumes a concentration of activities on functional areas as the basis for the implementation of regional policy in 2021-2027. This is to strengthen the functional links between rural areas and cities, which is important in the context of access to public services, the possibility of integrating bottom-up initiatives and a strategic approach in the regions, including from the point of view of balancing the effects of the pandemic in the actions of local governments (changes in income and expenditure, including restrictions on planned investment).

At the same time, it is necessary to point out the threats related to the sectoral approach to solving rural problems, especially in the field of infrastructure investment which will not be implemented under the CAP but under the instruments of the Cohesion Policy and the NRP. The studies conducted so far indicate that these funds have supported the development of socio-economic infrastructure in relatively well-developed territorial units, creating a threat in terms of exacerbating the development differences between rich municipalities, including those in the vicinity of large agglomerations, and peripheral areas struggling with the greatest problems in this regard (Komorowski, Mróz, and Stanny, 2021; Sánchez-Zamora and Gallardo-Cobos, 2020). 


\section{References}

Artelaris, P., Mavrommatis, G. (2020). Territorial Cohesion as a Policy Narrative: From Economic Competitiveness To 'Smart'Growth and Beyond. Social Inclusion, 8(4), pp. 208-217.

Bachtler, J., Mendez, C. (2020). 6 Cohesion and the EU Budget: Is Conditionality Undermining Solidarity?. Governance and Politics in the Post-Crisis Euradpean Union, 121.

Bachtler, J., Berkowitz, P., Hardy, S., Muravska, T. (2017). EU Cohesion Policy. Taylor \& Francis.

Berkowitz, P., Monfort, P., Pieńkowski, J. (2019). Unpacking the Growth Impacts of European Union Cohesion Policy: Transmission Channels From Cohesion Policy Into Economic Growth. Regional Studies.

Calabrò, F., Cassalia, G. (2017). Territorial Cohesion: Evaluating the Urban-Rural Linkage Through the Lens of Public Investments. International conference on Smart and Sustainable Planning for Cities and Regions (pp. 573-587). Cham: Springer.

Calegari, E., Fabrizi, E., Guastella, G., Timpano, F. (2020). EU Regional Convergence in the Agricultural Sector: Are There Synergies Between Agricultural and Regional Policies?. Papers in Regional Science.

Chmieliński, P., Feltynowski, M., Jachymek, M., Przybyłowski, A., Ziomek, A. (2008). Możliwości wsparcia rozwoju obszarów wiejskich $w$ wybranych politykach Unii Europejskiej. Program Wieloletni 2005-2009, No. 115. Warszawa: IERiGŻ-PIB.

Chmieliński, P., Gospodarowicz, M. (2018). A Regional Approach to Rural Development? Regional and Rural Programmes in Poland 2007-2015. Wieś i Rolnictwo, No. 4(181), pp. 181-198.

Copeland, P., Daly, M. (2018). The European Semester and EU Social Policy. JCMS: Journal of Common Market Studies, 56(5), pp. 1001-1018.

Czapiewski, K.Ł., Kulikowski, R., Bański, J., Bednarek-Szczepańska, M., Mazur, M., Ferenc, M., Konopski, M. (2013). The Use of ICT in Mazovian Agriculture. Rural Areas and Development, 10 , pp. 45-57.

Czyżewski, A., Stępień, S. (2015). Wspólna Polityka Rolna (WPR) Unii Europejskiej po 2014 roku z polskiej perspektywy. Problemy rozwoju rolnictwa $i$ gospodarki żywnościowej w pierwszej dekadzie członkostwa Polski w Unii Europejskiej, pp. 229-252.

Dax, T., Copus, A. (2018). Towards Vibrant, Inclusive and Sustainable Rural Regions: Orientations for a Future Rural Cohesion Policy. European Structural \& Investment Funds Journal, 6(3), pp. 198-209.

Dybikowska, A., Graczyk, M. (2019). Ekoinnowacje technologiczne związane z OZE - możliwości i bariery. Zagadnienia Ekonomiki Rolnej / Problems of Agricultural Aconomics, No. 1(358), pp. 120-139.

European Commission (2020). Zalecenia Rady z dnia 20 lipca 2020 r. w sprawie krajowego programu reform Polski na 2020 r., zawierające opinię Rady na temat przedstawionego przez Polskę programu konwergencji na 2020 r. (2020/C 282/21). Dziennik Urzędowy Unii Europejskiej C 282/135.

Graczyk, A. (2017). Rozwój odnawialnych źródeł energii w polskiej polityce regionalnej. Barometr Regionalny, 15(4), pp. 55-59.

GUS (2021). Infografika - Międzynarodowy Dzień Kobiet 8 marca 2021. Retrieved from: https://stat.gov.pl/infografiki-widzety/infografiki/infografika-miedzynarodowy-dzien-kobiet-8-marca-2021,25,6.html (access date: 20.01.2021).

Haefner, L., Sternberg, R. (2020). Spatial implications of digitization: State of the field and research agenda. Geography Compass, e12544, s. 1-16. Retrieved from: https://onlinelibrary. wiley.com/doi/epdf/10.1111/gec3.12544.

Hölzel, M., de Vries, W.T. (2021). Digitization as a Driver fur Rural Development - An Indicative Description of German Coworking Space Users. Land, 10(3), pp. 326. 
IERiGŻ-PIB (2016). Koncepcja przygotowania programu wieloletniego wspierającego realizację zadań inwestycyjnych w zakresie zaopatrzenia w wodę na obszarach wiejskich. Ekspertyza przygotowana dla MRiRW. Warszawa.

IERiGŻ-PIB (2018). Ocena zapotrzebowania obszarów wiejskich w niezbędną rozbudowę sieci kanalizacyjnej i oczyszczalnie ścieków, Ekspertyza przygotowana dla MRiRW. Warszawa.

Jaworska-Księżak, B. (2019). Potrzeby inwestycyjne jednostek samorządu terytorialnego po 2020 r. - czy stać nas na rozwój? Sprawozdanie z konferencji. MAZOWSZE Studia Regionalne, 28 , pp. 153-155.

Kanarek-Równicka, A. (2020). Działalność nieewidencjonowana a działalność gospodarcza. Analiza nowej regulacji prawnej. Studia Prawno-Ekonomiczne, 116, pp. 49-64.

Kępa A. (2015). Możliwości zmniejszenia wydatków związanych z ciepłą wodą użytkową. Rynek Energii, No. 4(119).

Kiryluk-Dryjska, E., Beba, P., Poczta, W. (2020). Local Determinants of the Common Agricultural Policy Rural Development Funds' Distribution in Poland and their Spatial Implications. Journal of Rural Studies, 74, pp. 201-209.

Kłodziński, M. (2010). Główne funkcje polskich obszarów wiejskich z uwzględnieniem dezagraryzacji wsi i pozarolniczej działalności gospodarczej. Studia BAS, 4, pp. 9-28.

Komornicki, T., Szejgiec-Kolenda, B., Degórska, B., Goch, K., Śleszyński, P., Bednarek-Szczepańska, M., Siłka, P. (2018). Spatial Planning Determinants of Cohesion Policy Implementation in Polish Regions. Europa XXI, 35, pp. 69-87.

Komorowski, Ł., Mróz, A., Stanny, M. (2021). The Spatial Pattern of the Absorption of Cohesion Policy Funds in Polish Rural Areas. Land, 10(1), pp. 26.

Krajowy Plan Odbudowy i Zwiększania Odporności (KPO). (2020). Serwis Rzeczypospolitej Polskiej GOV.PL. Retrieved from: https://www.gov.pl/web/planodbudowy (access date: 11.10.2020).

Mączyńska, E., Okoń-Horodyńska, E. (2020). Przedsiębiorstwo i jego otoczenie w obliczu czwartej rewolucji przemysłowej - Wyzwania, szanse i zagrożenia. Przeglad Organizacji, No. 1, pp. 9-21.

Mikuš, O., Kukoč, M., Rogelj, M.J. (2019). The Coherence of Common Policies of the EU in Territorial Cohesion: A Never-Ending Discourse? A Review. Agricultural Economics, 65(3), pp. 143-149.

Miller, S. (2014). Emerging Trends and Challenges in Community-Led Local Development (CLLD). European Structural \& Investment Funds Journal, Vol. 2, Issue 4, pp. 302-307.

Ministry of Development Funds and Regional Policy (2020a). Fiszka KPO Cyfryzacja (unpublished material from22.10.2020). Warszawa.

Ministry of Development Funds and Regional Policy (2020b). Założenia do Umowy Partnerstwa. Warszawa, February 2020.

Ministry of Development Funds and Regional Policy (2021). Projekt umowy partnerstwa dla realizacji polityki spójności 2021-2027 w Polsce. Warszawa.

Ministry of Agriculture and Rural Development (2019). Wstępne stanowisko resortu rolnictwa dotyczące wsparcia w ramach CP 2 - w zakresie: PSZOK, minimalizacji wytwarzania odpadów w procesach produkcyjnych, infrastruktury odpadów żywnościowych, działań edukacyjnych w ramach gospodarki o obiegu zamkniętym, w szczególności w zakresie sektora gospodarki odpadami, zakres wsparcia dotyczącego rozwoju zielonej infrastruktury w środowisku miejskim (September 2019). Warszawa (manuscript).

Ministry of Agriculture and Rural Development (2020). Rozwój Lokalny Kierowany przez Społeczność (RLKS). Retrieved from: https://www.gov.pl/web/rolnictwo/rozwoj-lokalny-kierowany-przez-spolecznosc-rlks (access date: 11.11.2020). 
Ministry of Agriculture and Rural Development (2020). Wstępne stanowisko MRiRW dot. CP3 i częściowo CP1 dot. wsparcia cyfryzacji (wstępne stanowisko MRiRW z listopada 2019 r.). Warszawa.

Minister for Economic Development (2016). Wytyczne w zakresie rewitalizacji w programach operacyjnych na lata 2014-2020. Warszawa.

Ministry of Economic Development, Labor and Technology (2020). Krajowy plan odbudowy: informacje i wyjaśnienia, Departament Analiz Gospodarczych. Warszawa, 9 October 2020.

Pollermann, K., Raue, P., Schnaut, G. (2014). Opportunities for a Participative Approach in Rural Development: Findings from LEADER in Mecklenburg-Vorpommern and the Requirements for Community Led Local Development. Landbauforschung Applied Agricultural Forestry Research, 64(3/4), pp. 127-138.

Radlińska, K.M. (2020). Pandemia COVID-19 implikacje dla polskiego rynku pracy. Zeszyty Naukowe Wydziału Nauk Ekonomicznych, 1(24), pp. 113-126.

Rauhut, D., Humer, A. (2020). EU Cohesion Policy And Spatial Economic Growth: Trajectories in Economic Thought. European Planning Studies, 28(11), pp. 2116-2133.

Rogowska, D. (2017). Wykorzystanie OZE w energetyce a zrównoważony rozwój. Nafta-Gaz, No. 8(LXXIII), pp. 616-623.

Rosner, A., Stanny, M. (2019). Przemiany struktury społeczno-zawodowej ludności wiejskiej. In: M. Halamska, M. Stanny, J. Wilkin (eds.), Ciagłość i zmiana: Sto lat rozwoju polskiej wsi, Vol. 1, pp. 119-146.

Sánchez-Zamora, P., Gallardo-Cobos, R. (2020). Territorial Cohesion in Rural Areas: An Analysis of Determinants in the Post-Economic Crisis Context. Sustainability, 12(9), pp. 3816.

Sierak, J. (2017). Rozwój i przestrzenne zróżnicowanie upowszechnienia infrastruktury wodociągowo-kanalizacyjnej w Polsce w latach 1995-2014. Nierówności społeczne a wzrost gospodarczy, No. 49, pp. 302-321.

Szukalski, P. (2020). Migrujące młode kobiety: przyczynek do badań nad przyczynami lokalnej depopulacji w Polsce. Demografia i Gerontologia Społeczna-Biuletyn Informacyjny, No. 4.

Tacoli, C. (1998). Rural-Urban Interactions: A Guide to the Literature. Environment and Urbanization, 10(1), pp. 147-166.

Wallace, H., Pollack, M.A., Roederer-Rynning, C., Young, A.R. (eds.). (2020). Policy-Making in the European Union. Oxford University Press.

Watzka, S., Watt, A. (2020). The Macroeconomic Effects of the EU Recovery and Resilience Facility. IMK Policy Brief, 98.

Wieliczko, B. (2017). Cohesion Policy or Common Agricultural Policy - Which of Them Is Better Suited to Support Rural Development in Poland?. Prace Naukowe Uniwersytetu Ekonomicznego we Wrocławiu, 466, pp. 236-243.

WISE Europa (2017).Wpływ Polityki Spójności 2007-2013 na konkurencyjność przedsiębiorstw i rozwój przedsiębiorczości w Polsce. Warszawa: MIiR.

Wrzaszcz, W., Prandecki, K. (2020). Rolnictwo a Europejski Zielony Lad. Zagadnienia Ekonomiki Rolnej / Problems of Agriculture Economics, No. 4(365), pp. 156-179.

Wysokiński, M., Trębska, P., Gromada, A. (2017). Energochłonność polskiego rolnictwa na tle innych sektorów gospodarki. Roczniki Naukowe SERiA, Vol. XIX, Issue 4, pp. 238-243. DOI: $10.5604 / 01.3001 .0010 .5193$.

Żbik, A. (2017). Wykrywanie podwójnego finansowania wydatków w projektach unijnych. Zeszyty Naukowe Politechniki Częstochowskiej. Zarzqdzanie, No. 28, Vol. 1, pp. 177-193. 


\title{
KOMPLEMENTARNOŚĆ DZIAŁAŃ WSPÓLNEJ POLITYKI ROLNEJ ORAZ POLITYKI SPÓJNOŚCI NA RZECZ ROZWOJU OBSZARÓW WIEJSKICH W LATACH 2021-2027 W ŚWIETLE DOKUMENTÓW PROGRAMOWYCH
}

\begin{abstract}
Abstrakt
Celem opracowania było określenie komplementarności polityki spójności $i$ wspólnej polityki rolnej $w$ zakresie ich oddziaływania na rozwój obszarów wiejskich w latach 2021-2027. Autorzy w swych badaniach szczególna uwage zwrócili na dystrybucję wsparcia pomiędzy wymienione polityki w kontekście wystepujacych na obszarach wiejskich problemów społecznych i gospodarczych. Materiat empiryczny stanowiła literatura przedmiotu oraz dokumentacja zwiazana z przygotowaniem oraz wdrażaniem analizowanych polityk.

Analiza dokumentów i literatury przedmiotu oraz praktyki wskazuja na rosnaca potrzebe wykazywania komplementarności obu polityk $w$ procesie programowania poszczególnych instrumentów rozwoju, zwłaszcza $w$ wymiarze terytorialnym, gdzie rozdzielenie poszczególnych aspektów życia społeczno-gospodarczego jest niezwykle trudne, stad potrzeba ponadsektorowego ujęcia, definicji i odpowiedzi na wyzwania lokalne.
\end{abstract}

Słowa kluczowe: polityka spójności, wspólna polityka rolna, komplementarność polityk publicznych.

Submission date: 25.02 .2021 .

Final review date: 21.03.2021.

Acceptance date: 12.04.2021.

Unless stated otherwise all the materials on the website are available under the Creative Commons Attribution 4.0 International license.

Some rights reserved to the Institute of Agricultural and Food Economics - National Research Institute.

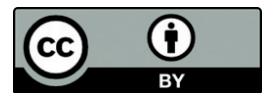

